\title{
THE “CLAWS OF ABSOLUTE NECESSITY”: DELEUZE ON CULTURE
}

\author{
By Andrew Iliadis
}

\section{The Object of Cultural Studies}

In this day and age of Žižekian rock star theorists and overly-abstruse philosophers, the institutional study of cultural theory can be understood as firmly entrenched in two camps. The first, pandering to the leftovers of the MTV generation and readers of Totem Books' Introducing series, are engaged in what can be called a type of theoretical bricolage; why shouldn't one be able to reference Lacan's borromean knot in a discussion of early nineties Norwegian black metal or 4G cellular wireless technology (from a Marxist perspective, of course)? The other camp, which often adheres to a strict nomenclature so esoteric that only those at the graduate level can penetrate their meaning, enjoys a certain performativity of the text; the form of their work, unlike the relatively straightforward and at times journalistic style of the former group, attempts to structurally mimic the logic of their thought. It could be called a type of philosophical, meta-textual performance art. This group would argue that essays have an aesthetic autonomy (see Theodor Adorno’s “The Essay as Form”). Each camp exists on one side of an invisible line that can be called the continental/analytic divide, and if we push this sensible difference further we can justifiably say that, in the last analysis, the difference is one of "positive" and "negative" thought; between a positivist logic founded on the necessity of presuppositions (the logic of word games, game theory, etc.) and a thought that is intrinsic, parasitic even, to thought itself (deconstruction, Gadamerian hermeneutics, etc.). One group envisions a need for answers while the other seeks to identify problems. This difference has been and might always be one of contentious debate, and it is certainly the locus of one of the chief frustrations permeating the theoretical realm of this ephemeral thing we call "Cultural Studies". 
At the institutional level, many of these frustrations emanate from the now-classic divide between the British and American schools of Cultural Studies. Tomes have been written on the alleged depoliticization of the field after its move across the pond (see Alan O'Connor's "The Problem of American Cultural Studies" for some superbly-argued pessimism) and in many cases the rise of a milquetoast "postmodernist" in the academy is understood as its direct correlate. Many of these essays argue that, where Cultural Studies came "crashing through the windows" for the British, it was not such an antagonistic force for the Americans. Stuart Hall, one of the great founders of Cultural Studies, has emphasized the fact that, for the Birmingham School, Cultural Studies announced itself as a type of intrusion; they did not anticipate it. In this original sense, a "cultural study" can be taken to mean the study of unknown cultural formations following the contingency of an encounter; according to Hall, "it is a project that is always open to that which it doesn't yet know, to that which it can't yet name" (263). One can say that the impetus behind the Cultural Studies explosion in America came from the counterintuitive tendency, compared to its British counterpart, of culling each and every popular topic under Cultural Studies' blindingly bright sun. Thus, legitimate material for cultural analysis included not only research on the social effects of new technologies such as television but also research on the popular programs that appeared long after the medium was created. In the American school in particular, there is a tendency to combine not different forms of inquiry but already established cultural phenomena the product of which then masquerades as a theoretical undertaking. We are hardly shocked, today, to see titles like The Sopranos and Philosophy: I Kill Therefore I Am littering the "Culture and Philosophy" sections of popular bookstores. These texts do not problematize philosophical concepts or even the nature of television technology and programming; their sole function is to explain one given with another in a type of never-ending 
cultural exegesis. Certain of the current works on television are just a few examples of the ongoing commodification of a cultural theory that posits presuppositions in place of original concepts in order to avoid new forms of thought. It comes as no surprise, then, that the same tendency towards presuppositions can also be found in what might be called the properly theoretical area of Cultural Studies.

The histories of post-Marxism and, in the past century, psychoanalysis have taught us to rearticulate our thoughts on ideology; the transcendental dialectics once pitted against false consciousness have been dismantled and, thanks to thinkers like Louis Althusser who focused on the psychological implications of Marx's theories, what was formerly a claim on enlightenment has converted to an acknowledgement of the necessary immanence of ideology itself for the human individual (see Althusser's “Ideology and Ideological State Apparatuses”). Today’s postmodern slogan might be "back to bare life", which should not be confused with Marx's concept of species being, in that the properly heterogeneous and interminable character of ideology is understood as an inextinguishable force that mobilizes every individual life, including those with recourse to a unifying collective "enlightenment". The case, we are told, makes itself clear when one thinks the problem of religion. The question of bare faith does not lend itself to dialectical critique. If we consider faith, as Jacques Derrida does, not as faith in some-thing but faith in faith, faith for faith's sake, then the question of false consciousness proves moot, if not irrelevant (76). Hans-Georg Gadamer poses the question in even plainer terms by using "religion" as a formal signifier to describe something of the faith-based character of every dialectical thought. "Has the end of an illusion arrived," Gadamer asks, or is that the illusion; "thinking that human beings can live without religion" (119)? It would seem, then, that 
the problem is one of accounting for the exigency of conflicting ideologies without reverting to a dialectics of transcendence.

Reengaging the problem of just what it means to "do" cultural theories might appear at first blush to require a reappraisal of neo-Marxist work on historical-material processes in order to develop new post-“post-ideological” forms of political economy. But can we really be critics of the bad kind of globalization, or, on the other hand, champions of a future of technologically enhanced equity enjoyed between nations of unequal geographic development without asking ourselves an altogether different set of questions? With any extended cultural study, it becomes increasingly evident that a return to an almost embarrassingly basic type of thinking is needed in order to realign Cultural Studies within a much broader philosophical program if we are to avoid the pitfalls of hypocrisy and dilettantism. How can we rescue Cultural Studies from the political whitewashing it has undergone over the course of its meteoric rise over the last few decades?

Without engaging in the practice of dialectical materialism, it would be helpful to pose ourselves a question on those terms; namely, what should be the object of Cultural Studies? The answer would tell us if we have any right of claiming an object at all. The remainder of this paper will argue that most forms of Cultural Studies presume to know this object too well, and that they wrongly presuppose its existence when and if they avoid the opposite, though no less disastrous, fate of perpetually quibbling over its definition. Georges Bataille, that great thinker of heterogeneity, offers us some potential clarity on the issue, in that

a shared orientation has, in itself, a constitutive value: it presupposes [...] the imperative character of the object. Unification, the principle of homogeneity, is only a tendential fact, incapable of finding in itself a motive for requiring and imposing its existence; and, in most 
circumstances, the recourse to an external requirement has the value of a primary necessity (my emphasis, 147).

The development of any system finds its predicate not in itself but in a heterogenous body that it excludes and which shapes its development. It is true that the Marxist tradition in cultural studies reserves a place for heterogeneity (Marx used the word "antagonism") underneath the various conflicts in society, but he also said that these antagonisms could be resolved by the objective conditions of reality once it has reached the stage of a totally transparent society. Cultural theory, far from believing its reality in the material world, should inherently teach that it is impossible to approach such a resolution even in the realm of discourse; to quote a couple of infamous and often misunderstood post-Marxists, "a non-exclusive public sphere of rational argument is a conceptual impossibility" (Laclau and Mouffe xvii). The reason for this is that concepts like hegemony and ideology could not exist if there were not some competing hegemonic or ideological force that impeded their full realization. According to this logic, there is always an imperative object that orients a homogeneous system but which, as we shall see, must necessarily remain unidentifiable if it is to continue to serve as the impetus behind the system's future efforts; once the imperative object becomes identifiable, it loses its radically heterogeneous character. As for cultural studies, the concept of heterogeneity, if addressed at the outset of potential projects, might help to inject it with a little bit of relevance. The palpable sense of conflict in the concept of heterogeneity need only be applied to a cultural studies methodology and directed at significant cultural events. In this way one might recognize that, as Ernesto Laclau and Chantal Mouffe do, plurality is not the phenomenon to be explained, but the starting point of the analysis (140). If a cultural study creates an identifiable object out of the epistemological framing of its planned project then the discourse's original raison d'être, 
according to the logic of its historic British interlocutors, has altogether disappeared.

Historically, cultural studies were concerned with investigating new forms of subjectivity after an encounter with the unknown rather than with perpetuating a phantom objectivity in the name of an academic, yet politically neutral, analysis of commodities. The problem, then, becomes a properly epistemological one: how should we think what it means to encounter a new subjectivity in a world of increasingly advanced capitalist practices?

\section{Deleuze and the "Object" of Thought}

The French philosopher Gilles Deleuze first attempted to think heterogeneity as a new type of difference within the realm of epistemology before turning to the investigation of how this change re-qualifies traditional notions of difference in history, culture, and communication in concrete social formations. He believed that to think was one thing, to think like a revolutionary another; the difference between the two being that the former is susceptible to participating in what is at its base a type of non-thought; that is, a thinking that is not its own; a thinking for the State. Deleuze warns us towards the end of $A$ Thousand Plateaus: "the less people take thought seriously, the more they think in conformity with what the State wants" (376). Thought, as we have been told throughout the history of Marxism, produces concrete effects; certain strands of continental philosophy have also taught us that material substances affect thought; the mind/matter debate is no longer a question for the thinkers of these strands. Philosophy long ago stripped the Cartesian cogito of its transcendence and today theorists can say that the force that is active behind the words "to think" exists on the same plane as a cinder block. Deleuze, following Spinoza, was well aware of this point (his second doctoral thesis, one of the requirements of the French system at the time, was a book-length project on Spinoza). However, even in some of his later texts, Deleuze continued to emphasise what has, for most, 
become an elementary philosophical position: namely, that "concepts are inseparable from affects, i.e. from the powerful effects they exert on our life, and percepts, i.e. the new ways of seeing or perceiving they provoke in us" (Two Regimes of Madness 238). In other words, both Thought and Matter are co-dependent elements on the same folded line where they have an equal stake in the actual construction of our reality; but this is pure Spinozism.

Deleuze introduced the most radical extension of this philosophy by opening a caesura within thought itself and by "thinking beyond concepts" as it were. In an effort to expose the prejudice of thought (the thought that our thinking has a "good nature") he attempted to formulate a philosophy that would allow us to reconsider the way in which we thought thought, and it involves a type of Nietzschean overturning that is suspicious of cognisance itself as it tries to remain open to that which thought cannot lay claim to. It is a reaching beyond the concept that stretches thought to events located at the limits that necessitate thought a priori. In his primary doctoral dissertation that would go on to become one of the crowning achievements of his philosophical oeuvre, Deleuze began to articulate this new overturning:

Concepts only ever designate possibilities. They lack the claws of absolute necessity - in other words, of an original violence inflicted upon thought; the claws of a strangeness or an enmity which alone would awaken thought from its natural stupor or eternal possibility: there is only involuntary thought, aroused but constrained within thought, and all the more absolutely necessary for being born, illegitimately, of fortuitousness in the world. Thought is primarily trespass and violence, the enemy, and nothing presupposes philosophy: everything begins with misosophy. Do 
not count upon thought to ensure the relative necessity of what it

thinks. Rather, count upon the contingency of an encounter with that which forces thought to raise up and educate the absolute necessity of an act of thought or a passion to think (my emphasis, Difference and Repetition 139).

Deleuze's remarks on the nature of conceptualization differ radically from the positivist notions of thought introduced throughout the Enlightenment and that continue to this day in fields as different as Cultural Studies and ego psychology. In order to understand what is at stake in cultural formations, he posits something like a first axiom: if the task of thought is supposed to be the construction of new ways of understanding, then it must necessarily seek to avoid all of the "identitarian" presuppositions that, strictly speaking, are not a form of thought. For all their differences, the contemporary philosophical equivalent of this thought would be found in Alain Badiou's conceptualization of "nonidentitarian" politics in his Saint Paul: The Foundation of Universalism. Badiou states that "there exists a despicable complicity between the globalized logic of capital and [...] identitarian fanaticism” (9). Later, Badiou, who praises Deleuze for his singularity but who also adheres to certain tenets of a psychoanalysis that Deleuze despised, admits that "Deleuze put it perfectly" in pointing out that capital "demands a permanent creation of subjective and territorial identities in order for its principle of movement to homogenize its space of action" (10-11). What is most interesting is that Badiou's later texts, Saint Paul especially, seem to move closer to Deleuze's conception of the immanent enthusiasm of thought. For Deleuze, as for Badiou, capital and thought are almost diametrically opposed; the first depends on a value generated by the repetition of a type of identitarian thought while the second can exist only when there is an encounter with a type of radical heterogeneity. 
According to Deleuze, the New (a type of new subjectivity) does not come from any previously existing incarnation that can be thought; it does not come from our powers of recognition (thus his customary theoretical refashioning of thinkers and artists, and also his rather contentious titling of essays such as "May '68 Did Not Take Place"). What becomes established with the New is precisely not the New. The New - as difference - inaugurates forces in thought which are "not the forces of recognition, today or tomorrow, but the powers of a completely other model, from an unrecognized and unrecognizable terra incognita" (Difference and Repetition 136). The New is the product of a fundamental encounter; it is a type of "knowledge", gained at the expense of the unknowable territory, Deleuze's terra incognita, germinating forth out of an infinite amount of antagonistic concepts that are situated on top of an inaccessible plane of immanence (Difference and Repetition 139). It is only when these antagonistic concepts collide that an event is created and the space for thinking occurs. Thus, Deleuze's second axiom: the New announces itself conceptually via a type of ruptural event. The New is ushered in by the event; it is a type of pure heterogeneity, an infinite source of virtual vibrations on the plane of immanence begging to be actualized. If cultural theorists have truly finished with metanarratives, then there can only be heterogeneous beginnings. The object of Cultural Studies as a discipline in the Humanities should then be to think the place from which these beginnings are born by interrogating the way we conceptualize these beginnings and our complicity in the creation of fraudulent thought (or what can be called a kind of false start). The latter thought is a slow image of thought, compared to the proliferation of heterogeneous encounters on the plane of immanence that inaugurates new subjectivities. Like Deleuze, theorists who find their home in Cultural Studies departments should attempt to avoid this natural stupor. The creation of a space for the appearance of the New, for new individualities and 
new identities comes first not from the old image of thought but as a consequence of a multitude of infinitely quick symbiotic struggles whose subsequent mutations are then "comprehended" or conceptualized by a posteriori thoughts; thought plays catch up with the event. Since they are always lagging behind, there are dangers in using the old tools of consciousness to understand the New, from misunderstood racism in the streets to male chauvinism in the academy.

Revolutionary thinking is not found in thinking as repetition - recognition - but in thinking as differential repetition initiated by an event. It is intimately linked to a "significant" event, the radically heterogeneous properties of which should not be forgotten. It is a type of absolute deterritorialization, a term that signifies both a space for new zones of becoming and the potentiality for the actualization of the terra incognita without reference to manifest content. As a concept and as an event, revolutionary thinking is "self-referential or enjoys a self-positing that enables it to be apprehended in an immanent enthusiasm without anything in states of affairs or lived experience being able to tone it down, not even the disappointments of reason" (What is Philosophy? 101). Basically, and this applies to socio-political events as much as to philosophical ruptures, it is a matter of thinking the event, the previously unthought-of, in a way that leads to the production of new agencies of enunciation ("new tools"), and so the task of revolutionary thinking given to a discourse like Cultural Studies becomes letting new subjectivities announce themselves after an evental rupture (these events are always described in the news media as "dangerous", "unnecessary", or just lacking common sense). This is significantly different from saying "the event gives us something new" in that it does not presuppose to know what the imperative object is. In the rupture initiated by the evental site the new never is; it is only made possible by the agency of the event and this is why the event itself must be called evental. Like Deleuze, cultural theorists could not overstress this point when 
confronting potential projects. In the deceivingly complex short essay "May '68 Did Not Take Place," Deleuze articulated this process:

The possible does not pre-exist; it is created by the event. It is a question of life. The event creates a new existence, it produces a new subjectivity (new relations with the body, with time, sexuality, the immediate surroundings, with culture, work...). When a social mutation appears, it is not enough to draw the consequences or effects according to lines of economic or political causality.

Society must be capable of forming collective agencies of enunciation that match the new subjectivity, in such a way that it desires the mutation. That's what it is, a veritable redeployment (my emphasis, Two Regimes of Madness 234).

Deleuze teaches us that not only is it counterproductive to consider the apparently $a$ priori constituent elements of the event but that it is really a form of fraudulent thought that allows us to do so. Such thinking builds itself on a foundation, which is misunderstood as natural or rational. It is a thinking that reinstalls the metanarrative. The singularly unique function of evental sites is that they necessarily come before the conceptualization or the discursive demarcation of their components. The third axiom might be that the "concept" does not "cohere". Instead, the "concept speaks the event, not the essence or the thing" (What is Philosophy? 21). It is in this sense that the event can never be extinguished; it is, rather, an infinite source for openings and the zone of a never ending birth. It would not be going too far, then, to say that simultaneously and opposite this, in the moment of their foundation, concepts and their components (whether they be historical, ontological, ideological) are, in a way, already 
in danger of being en route to their destruction, their closure or at the very least, their selfcontradiction; "every detour is a becoming-mortal" (Essays Critical and Clinical 2). According to this logic, it is easy to see how Deleuze's philosophy is often misappropriated by theorists and especially artists and cultural commentators who make him out to be something like the philosophical equivalent of such banal bourgeois sayings as “express yourself". It is, also, somewhat ironic that, before his suicide, Deleuze was working on a new monograph entitled The Grandeur of Marx (Thoburn 1). We can only speculate as to what the final product might have looked like, yet it is safe to say that Deleuze's approach would have been one far removed from a type of naïve, commonsense privileging of an identity politics that is strangely aligned with capitalism in the name of revolutionary cultural praxis. This, one can argue, is instead the myopic logic informing detours through object analysis as they are expressed in contemporary Cultural Studies. 


\section{Works Cited}

Badiou, Alain. Saint Paul: The Foundation of Universalism. Trans. Ray Brassier. Stanford: Stanford University Press, 2003.

Bataille, Georges. Visions of Excess: Selected Writings, 1927-1939. Ed. Allan Stoekl. Trans. Allan Stoek1. Minneapolis: University of Minnesota Press, 2006.

Deleuze, Gilles. A Thousand Plateaus: Capitalism and Schizophrenia. Trans. Brian Massumi. Minneapolis: University of Minnesota Press, 1987.

—. Difference and Repetition. Trans. Paul Patton. New York: Columbia University Press, 1994.

-. Essays Critical and Clinical. Trans. Daniel W. Smith and Michael A. Greco. Minneapolis: University of Minnesota Press, 1997.

—. Two Regimes of Madness: Texts and Interviews 1975-1995. Ed. David Lapoujade. Trans. Ames Hodges and Mike Taormina. New York: Semiotext(e), 2006.

- What Is Philosophy? Trans. Hugh Tomlinson and Graham Burchell. New York: Columbia University Press, 1994.

Derrida, Jacques. "Above All, No Journalists!" Religion and Media. Ed. Hent de Vriess and Samuel Weber. Trans. Samuel Weber. Stanford University Press, 2001.

Gadamer, Hans-Georg. Hermeneutics, Religion, and Ethics. Trans. Joel Weinsheimer. Yale University Press, 1999.

Hall, Stuart. Critical Dialogues in Cultural Studies. Ed. David Morley and Kuan-Hsing Chen. London: Routledge, 1996.

Laclau, Ernesto and Chantal Mouffe. Hegemony and Socialist Strategy: Towards a Radical Democratic Politics. Second Edition. New York: Verso, 2001.

Thoburn, Nicholas. Deleuze, Marx and Politics . London: Routledge, 2003. 